\title{
Potential Analysis of Ex-Coal Mining Land As Pumped Storage Hydro Powerplant In Kutai Kartanegara, East Kalimantan
}

\author{
Yollanda Z. Devi ${ }^{1, *}$, Andang W. Harto ${ }^{1}$, Rachmawan Budiarto ${ }^{1}$, and Novi Trihastuti $^{2}$ \\ ${ }^{1}$ Department of Nuclear Engineering and Engineering Physics, Universitas Gadjah Mada, Yogyakarta, Indonesia \\ ${ }^{2}$ PT. ASI Pudjiastuti Geosurvey, Jakarta Indonesia \\ *yollandazd@gmail.com
}

\begin{abstract}
The growth of electricity demand will increase $56.8 \%$ in 10 years. Meanwhile, the fulfillment of electricity in Indonesia is dominated by coal. The amount of electricity growth has not balanced yet by the amount of electricity supply. It causes the electricity deficit in some areas, especially at the peak load period. One of the areas that often have electrical power deficit is East Kalimantan, although the province is one of the biggest coal mining areas in Indonesia. The mining activities give several impacts in environmental damages especially in the ex-coal mining land which has not been well managed. The impact includes an irreversible change of landscape and huge craters caused by open mining activities. In this study, an analysis is conducted for utilization of ex-coal mining land in Kutai Kartanegara as a reservoir of energy storage system type Pumped Hydroelectric Storage (PSH). The analysis provides a comparison of three variations of the piping line system. The study uses the spatial data in the form of Digital Elevation Model (DEM) to calculate the time of starting operation system, expected generated energy, required energy for power plant operation and the efficiency of the system. This study compares some criteria based on three variations of the piping line system and the effect on the efficiency of the system. Keywords - Pumped Storage Hydro Powerplant, starting operation time, energy turbine, energy of pump, efficiency
\end{abstract}

\section{Introduction}

The electricity demand continuously increases until $56.8 \%$ in 10 years, from $637.7 \mathrm{kWh} /$ person in 2010 to $999.9 \mathrm{kWh} /$ person in 2020 [1]. The growth of electricity demand cannot be balanced by the growth of electricity supply yet. It causes electrical power deficit in some areas, especially in the peak load period. One of the electrical networks that often have electrical power deficit is Mahakam System.

In the other hand, an area covered the Mahakam System is Kutai Kartanegara which has many coal mining activities. The mining activities there causes the environmental damage. Most of the mining areas were originally forest area which became the ex-coal mining land [2]. The coal mining process which uses the open mining technique with dig and fills method but does not provide proper reclamation and revegetation will cause the formation of huge craters. The formation of huge craters that represents irreversible environment damage gives the opportunity to be transformed as Pumped Storage Hydro Powerplant (PSH). The using of ex-coal mining land as the reservoir of PSH system in Kutai Kartanegara can be a part of the solution to electrical power deficit in Mahakam System electrical network.
The system is a hydropower generation system operated to fulfill the electrical demand, especially in the peak-load period. The system requires two water reservoirs in operation, called upper reservoir and lower reservoir. When the electricity demand is above the baseload, the system will flow the water from the upper reservoir to lower reservoir to rotate the turbine. It is called as a discharging mode. Whereas, when the electricity demand is below the base-load, available energy surplus will be consumed by the PSH system to pump the water from lower reservoir to upper reservoir. It is called as charging mode [3]-[7].

This study analyzes the energy produced, the energy needed, starting time operating system and efficiency of the system of the PSH system using the ex-coal mining land in Sanga-Sanga district, Kutai Kartanegara, East Kalimantan. This study uses GIS data which is gotten from LiDAR aerial remote sensing survey in 2014. This study presents an overview and recommendation of exmining land utilization as PSH.

\section{Methodology}

\subsection{Literature Study}


After reviewing several relevant kinds of literature, then study conducts collecting data, data processing, and analysis. This study requires the geographical data of two ex-coal mining pits as a potential site being analyzed.

Geographical information is analyzed to determine form and volume of craters. The data provide a basis to estimate expected power generation due to available head and discharge as well as the volume of starter water. The other data needed is the local meteorological data to calculate the addition of water stored annually. It is also used to estimate the starting operation time based on the volume of water in the storage.

Data analysis is conducted in some steps as follow :

- Generating a contour based on map in the form of Digital Elevation Model (DEM) using Global Mapper 10

- $\quad$ Sampling the contour data per $1 \mathrm{~m}$ using ArcMap 11

- Calculating the volume and area based on contours using Global Mapper 10

- Implementing regression method to know the function of depth and area also depth and volume

- Estimating additional water in the storage from the local rainfall rate

- Calculating the rate of evapotranspiration and infiltration based on local climate data

- Estimating the net discharge addition of water in the storage

- $\quad$ Estimating the time when upper reservoir being filled until $0 \mathrm{~m}$ height of water surface

- $\quad$ Providing the side view contour of both reservoir

- Designing the piping system

- $\quad$ Calculating the energy of pump and turbine energy in a cycle

- Calculating the efficiency of the system

\section{Results and Discussion}

\subsection{Description of Site Study and Pumped Storage Hydro Powerplant Plan Design}

The study site is ex-coal mining land which is located in Sanga-Sanga, Kutai Kartanegara, East Kalimantan Province. The study selects two craters with different depth. The coordinate of upper reservoir is $0^{\circ} 41^{\prime} 45^{\prime \prime} \mathrm{S}$ and $117^{\circ} 14^{\prime} 15^{\prime \prime} \mathrm{E}$, and the coordinate of the lower reservoir is $0^{\circ} 40^{\prime} 45^{\prime \prime} \mathrm{S} 117^{\circ} 14^{\prime} 38^{\prime \prime} \mathrm{E}$. Fig. 1 is the orthophoto data of ex-coal mining land which is used as the study site.

Both reservoirs in the site have the same height but different depth and volume. The upper reservoir has a smaller volume and lower depth than the lower one. The different depth between two reservoirs is the basic variable to use them as the reservoir of PSH system. Based on the formation of the site, the piping system will be built underground.

\subsection{Estimation of Starting Time Operation System}

The rainfall is the water source for two ex-coal mining craters used in this study. This PSH system can start to operate when the upper reservoir is filled by rainfall until
$0 \mathrm{~m}$ height of water surface (see Fig. 1). The study considers the water losses caused by evapotranspiration and percolation. Mathematically, the equation of additional net volume can be written as follow

$$
\begin{aligned}
& V_{\text {net }}=V_{r}-V_{e}-V_{p} \\
& V_{p}=v_{p} \times A_{p} \times t \\
& V_{e}=v_{e} \times A_{e} \times t
\end{aligned}
$$

Where :

$$
\begin{array}{ll}
V_{\text {nett }} & : \text { net volume }\left(\mathrm{m}^{3}\right) \\
V_{p} & : \text { percolation volume }\left(\mathrm{m}^{3}\right) \\
V_{e} & : \text { evapotranspiration volume }\left(\mathrm{m}^{3}\right) \\
v_{p} & : \text { the rate of percolation }(\mathrm{m} / \text { year }) \\
v_{e} & : \text { the rate of evapotranspiration }(\mathrm{m} / \text { year }) \\
A_{p} & : \text { percolation area }\left(\mathrm{m}^{2}\right) \\
A_{e} & : \text { evapotranspiration area }\left(\mathrm{m}^{2}\right) \\
t & : \text { time (year) }
\end{array}
$$

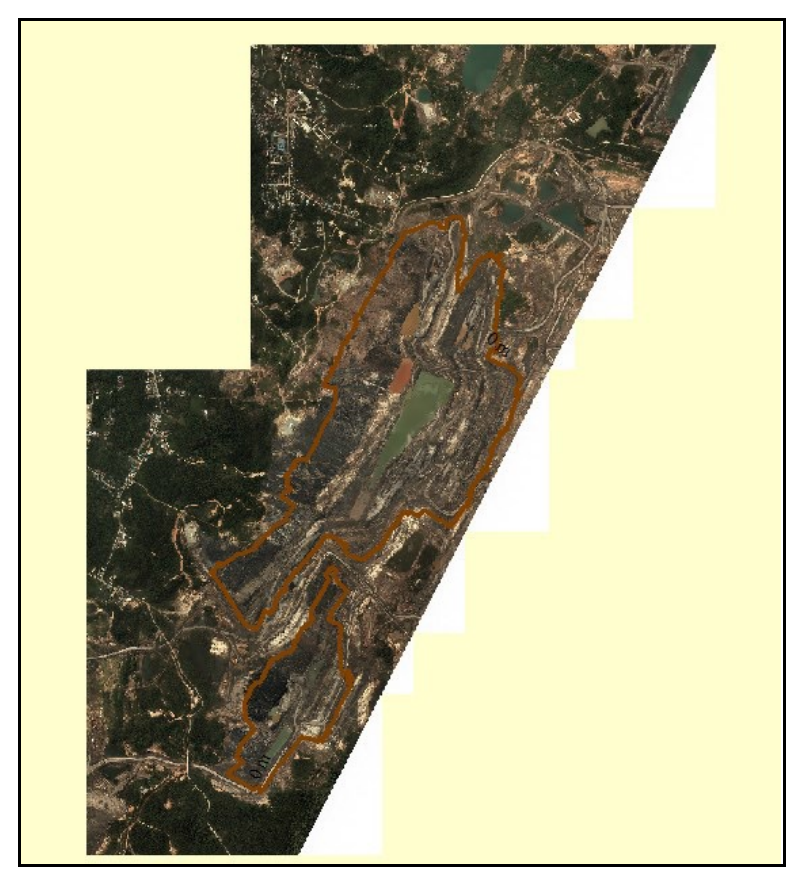

Fig. 1. Orthophoto of ex-coal mining land as site study

Based on climate data, the local rainfall rate is about $2.695 \mathrm{~m} /$ year [8], percolation rate is $0.73 \mathrm{~m} /$ year [8] and evapotranspiration rate is about $0.535 \mathrm{~m} /$ year [9].

The time when the upper reservoir is filled by the water can be found by knowing the volume and area of the upper reservoir in each height. Fig. 2 below shows the graph of depth to area of both reservoirs. Fig. 3 shows the graph of depth to volume of both reservoirs.

Based on the data, the net additional volume in a year is about $1,417,570 \mathrm{~m}^{3}$. The estimation of starting operation time of this PSH system is about 14.7 years later, or 2028. In that time, the height of water surface is $-0.087 \mathrm{~m}$ for the upper reservoir and $-48.002 \mathrm{~m}$ for the lower reservoir. 


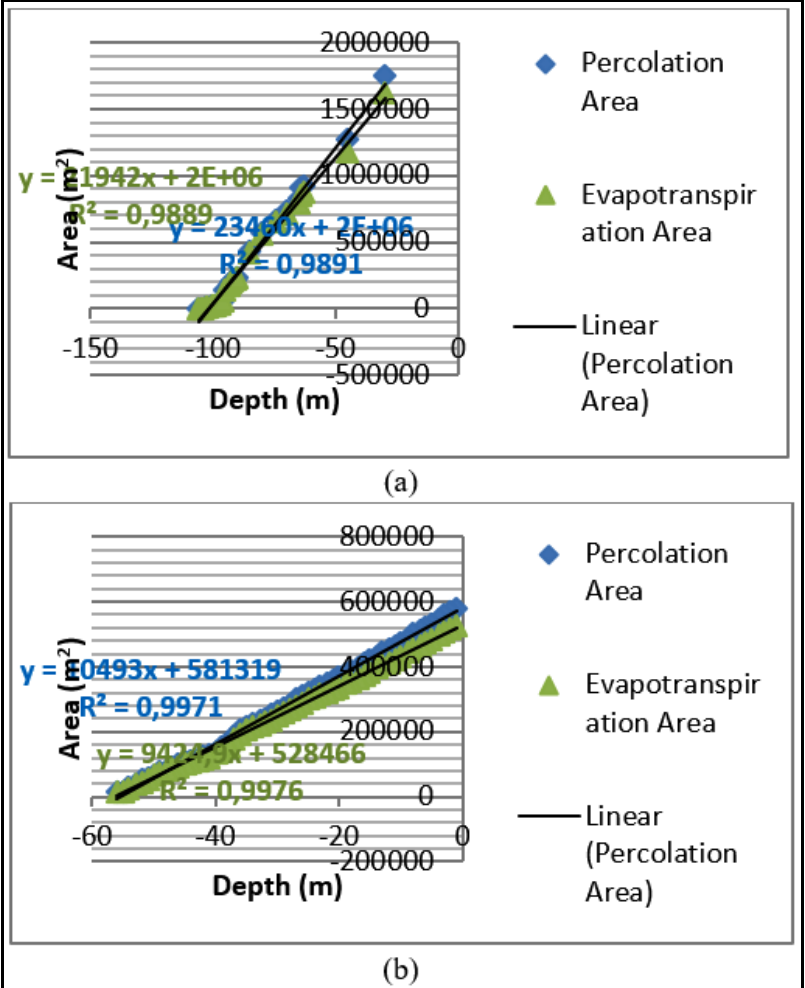

Fig. 2. The depth vs. area of reservoir graph (a) Lower reservoir (b) Upper reservoir

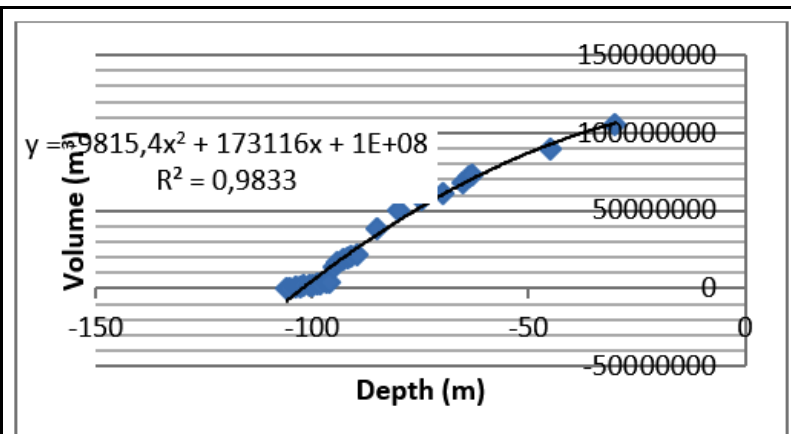

(a)

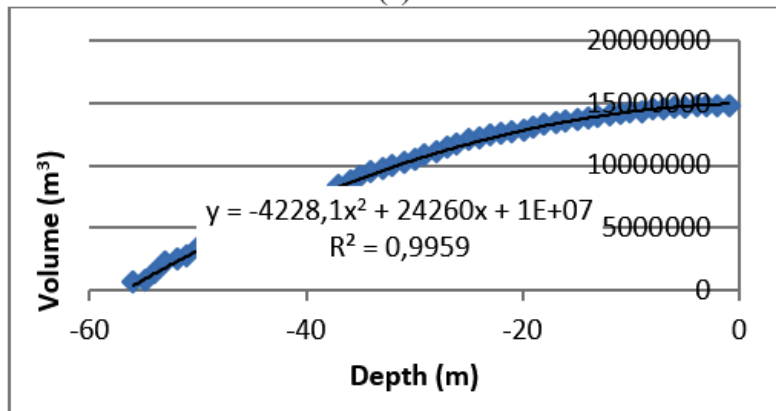

(b)

Fig. 3. The graph of depth to volume of reservoir (a) Lower reservoir (b) Upper reservoir

\subsection{Pipeline Design}

This study uses three variations of the pipeline for Pumped Storage Hydro Powerplant (PSH) system. They are pipeline A, pipeline $\mathrm{B}$, and pipeline C. Fig. 4 shows the three pipeline designs used in this study

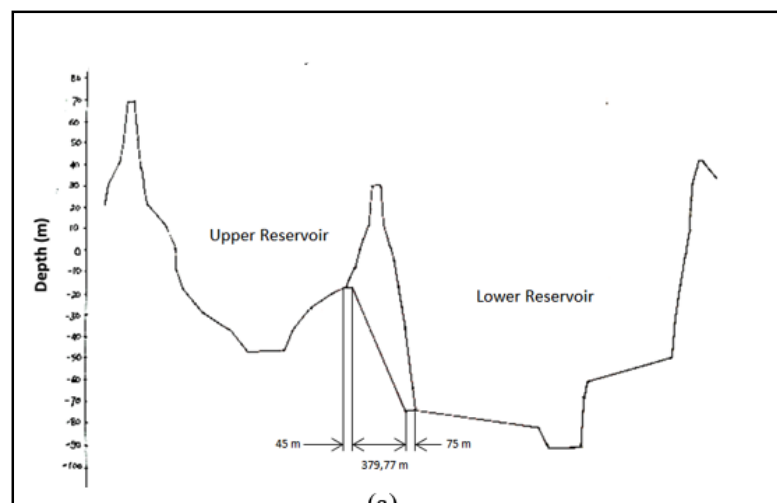

(a)
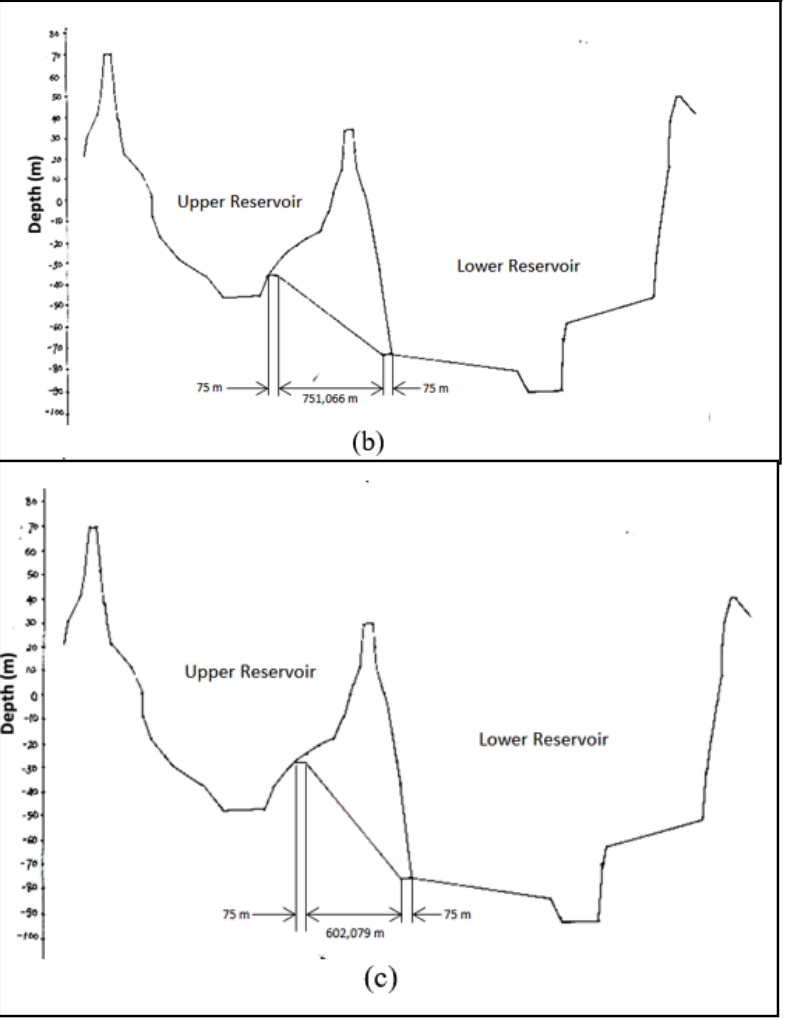

Fig. 4. Layout design of pipeline (a) Design A (b) Design B (c) Design $\mathrm{C}$

The length of pipeline $\mathrm{A}$ is about $502.77 \mathrm{~m}$, pipeline B is about $904.066 \mathrm{~m}$, and pipeline $\mathrm{C}$ is about $755.079 \mathrm{~m}$. The longer pipeline, the greater head loss will be produced because due to the greater friction. It will influence the amount of power produced by the PSH system. Each pipeline design has $4 \mathrm{~m}$ in diameter.

\subsection{Energy of Turbine}

Therefore, turbine power produced by the PSH system in this study is not constant at the time. It because the flow rate of the water depends on the hydrostatic pressure which declines by the time. The highest power of the system is obtained when the water surface is at the maximum level. The change of flow rate occurs due to the change of water level which causes variation of hydrostatic pressure. 


$$
\begin{aligned}
& \frac{d Z_{H}}{d t}=\frac{-v \cdot A_{p}}{\left(A_{H}\left(Z_{H}\right)+Z_{H} \frac{d A_{H}}{d Z_{H}}\right)} \\
& \frac{d Z_{H}}{d t}=\frac{-12,56 \sqrt{\frac{2 g\left(Z_{H}(t)-Z_{L}(t)\right)}{\left(K+\frac{0,184 L}{\left(\frac{\rho v s D}{\mu}\right)^{0,2 D}}\right)}}}{\left(18849,8 Z_{H}(t)+528466\right)}
\end{aligned}
$$

Where :

$$
Z_{H} \quad: \text { water level in upper reservoir (m) }
$$

$Z_{L} \quad:$ water level in lower reservoir (m)

$g \quad$ : gravitational acceleration $\left(\mathrm{m} / \mathrm{s}^{2}\right)$

$\rho \quad:$ water density $\left(\mathrm{kg} / \mathrm{m}^{3}\right)$

$v \quad:$ flow rate $(\mathrm{m} / \mathrm{s})$

D : inner diameter of pipe

$\mu \quad$ : water viscosity $(\mathrm{kg} / \mathrm{ms})$

$L \quad$ : length of pipeline (m)

$K \quad$ : friction coefficient

$A_{H} \quad$ : surface area of upper reservoir water level $\left(\mathrm{m}^{2}\right)$

Equation (4) is applied to calculate the declining rate of water level in the upper reservoir. Substituting variables of the study site into (4) gives (5).

$$
\begin{gathered}
\frac{d Z_{L}}{d t}=\frac{v \cdot A_{p}}{\left(A_{L}\left(Z_{L}\right)+Z_{L} \frac{d A_{L}}{d Z_{L}}\right)} \\
12,56 \sqrt{\frac{2 g\left(Z_{H}(t)-Z_{L}(t)\right)}{\left(K+\frac{0,184}{\left(\frac{\rho v D}{\mu}\right)^{0,2}} \frac{L}{D}\right)}} \\
\frac{d Z_{L}}{d t}=\frac{\sqrt{\left(43884 Z_{L}(t)+2000000\right)}}{(K+2)}
\end{gathered}
$$

Where

$A_{L}$ : surface area of lower reservoir water level $\left(\mathrm{m}^{2}\right)$

Furthermore, (6) is applied to calculate the increasing rate of water level in the lower reservoir. Substituting variables representing the study site into (6) gives (7).

$$
v^{2}+\frac{0,184}{\left(\frac{\rho D}{\mu}\right)^{0,2}} \frac{L}{K D} v^{1,8}-\frac{2 g\left(Z_{H}-Z_{L}\right)}{K}=0
$$

Then, the flow rate of the water in discharging mode can be found by solving the root of flow rate quadratic (8). Equation (8) can be solved by using Secant method. To find the value of $Z_{H}$ and $Z_{L}$, Runge-Kutta numerical method has to be done with the initial condition $Z_{\mathrm{H}}(0)=$ $0.087 \mathrm{~m}$ and $\mathrm{Z}_{\mathrm{L}}(0)=-48.002 \mathrm{~m}$.

$$
P=\frac{1}{2} \cdot \rho \cdot A_{p} \cdot v^{3}
$$

Based on the calculation using that equation, the power of turbine can be found by using (9) above

Where :

$P \quad$ : the power generated by turbine (W)
The power of turbine will decline by the time due to the declining of hydrostatic pressure as shown in Fig. 5

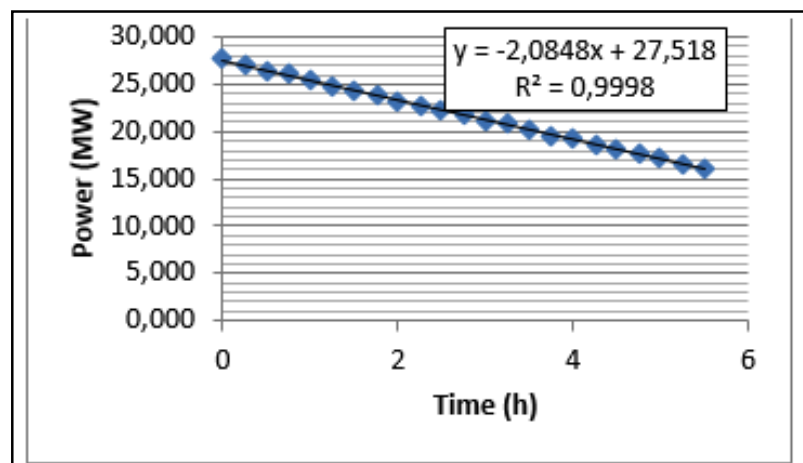

(a)

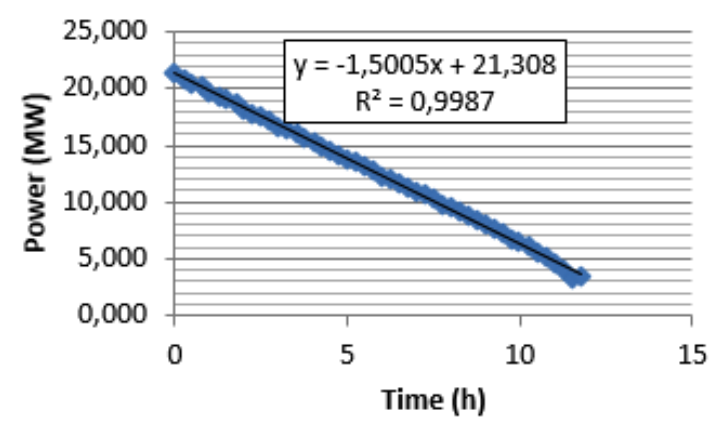

(b)

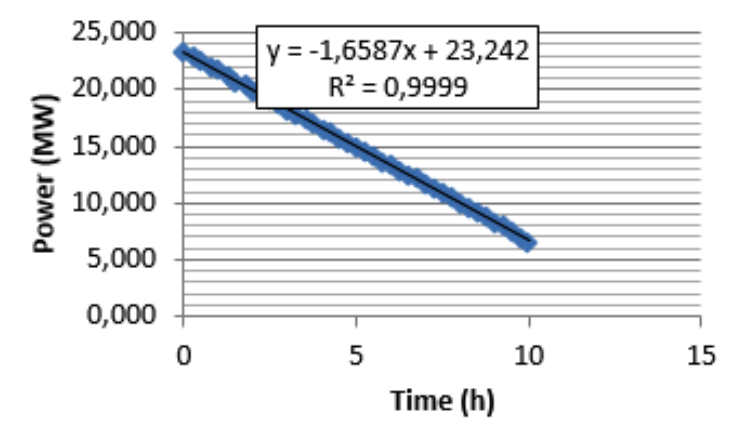

(c)

Fig. 5. The power generated vs. time graph (a) Design A (b) Design B (c) Design C

The operation time of turbine per cycle can be done until the water level is $10-15 \mathrm{~m}$ above the pipeline because the pipeline has to be submerged in water. $10-15 \mathrm{~m}$ is chosen by considering the fluctuation of declining water. Based on the calculation, the operation time of turbine per cycle is 5.5 hours for design A, 12.25 hours for design B and 10 hours for design $\mathrm{C}$. So, mathematically the energy produced by the turbine in a cycle can be written as (10) (12)

a. Pipeline A

$$
E_{\text {turbine }}=\int_{0}^{5.5}-2.0848 t+27.518 d t
$$

b. Pipeline B 


$$
E_{\text {turbine }}=\int_{0}^{12.25}-1.5106 t+21.348 d t
$$

c. Pipeline C

$$
E_{\text {turbine }}=\int_{0}^{10}-1.6587 t+23.242 d t
$$

Where :

$$
E \text { : energy produced by turbine (MWh) }
$$

Based on those equations, the energy produced by the systems are 119.8164 MWh for pipeline A, 146.788 MWh for pipeline B, and 149.485 MWh for pipeline C.

\subsection{Energy of Pump}

At charging mode, the flow rate of water will decline at the time. It is also caused by the changing of hydrostatic pressure.

$$
\begin{aligned}
& \frac{d Z_{H}}{d t}=\frac{v \cdot A_{p}}{\left(A_{H}\left(Z_{H}\right)+Z_{H} \frac{d A_{H}}{d Z_{H}}\right)} \\
& \frac{d Z_{H}}{d t}=\frac{12,56 \sqrt{\frac{2 g\left(Z_{H}(t)-Z_{L}(t)\right)}{\left(K+\frac{0,184}{\left(\frac{\rho v D}{\mu}\right)^{0,2}} \frac{L}{D}\right)}}}{\left(18849.8 Z_{H}(t)+531222\right)}
\end{aligned}
$$

Equation (13) is applied to calculate the increasing rate of water level in the lower reservoir. Substituting variables of the study site into (13) gives (14).

$$
\begin{aligned}
& \frac{d Z_{L}}{d t}=\frac{-v \cdot A_{p}}{\left(A_{L}\left(Z_{L}\right)+Z_{L} \frac{d A_{L}}{d Z_{L}}\right)} \\
& \frac{d Z_{L}}{d t}=\frac{-12,56 \sqrt{\frac{2 g\left(Z_{H}(t)-Z_{L}(t)\right)}{\left(K+\frac{0,184}{\left(\frac{\rho v D}{\mu}\right)^{0,2}} \frac{L}{D}\right)}}}{\left(44348 Z_{L}(t)+2000000\right)}
\end{aligned}
$$

Furthermore, (15) is applied to calculate the declining rate of water level in the lower reservoir. Substituting the study site into (15) gives (16).

Furthermore, the flow rate of the water in charging mode can be found by solving the root of the flow rate quadratic equation below.

$$
\begin{aligned}
& \frac{K \rho}{2} v_{\text {pump }}{ }^{3}+\frac{0,184 . L . \rho}{\left(\frac{\rho D}{\mu}\right)^{0,2} \cdot 2 D} v_{\text {pump }}{ }^{2,8}+\rho g\left(Z_{H}-Z_{L}\right) v_{p} \\
& \eta \frac{W_{\text {pump }}}{A_{p}}=0
\end{aligned}
$$

To determine the value of $\mathrm{Z}_{\mathrm{H}}$ and $\mathrm{Z}_{\mathrm{L}}$, Runge-Kutta numerical method has to be applied with the certain initial condition. The initial condition of charging mode is equal to the final condition of discharging mode. So, the initial condition of the design $\mathrm{A}$ is $\mathrm{Z}_{\mathrm{H}}(0)=-9.930 \mathrm{~m}$ and $Z_{L}(0)=-43.685 \mathrm{~m}$, the initial condition of the design $B$ is $Z_{\mathrm{H}}(0)=-26.080 \mathrm{~m}$ and $Z_{\mathrm{L}}(0)=-40.734 \mathrm{~m}$, and the initial condition of the design $\mathrm{C}$ is $\mathrm{Z}_{\mathrm{H}}(0)=-20.313 \mathrm{~m}$ and $\mathrm{Z}_{\mathrm{L}}(0)$ $=-41.325 \mathrm{~m}$.

The charging mode would be operated until the water level is about $0 \mathrm{~m}$. The time needed to pump the water from lower to the upper reservoir in each pipeline is 5.75 hours for pipeline A, 12.25 hours for pipeline B, and 10 hours for pipeline $\mathrm{C}$.

$$
E_{\text {pump }}=W_{\text {pump }} \times t
$$

Where :

$\mathrm{P}_{\text {ump }} \quad$ : energy needed by pump (MWh)

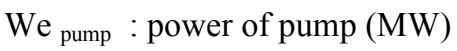

t $:$ time (h)

Then, the amount of energy needed by pump can be solved by using (17)

Pump power needed by the PSH system is assumed to equal to the maximum power produced by the turbine. Based on the (17), the energy needed by the pump for the design $\mathrm{A}, \mathrm{B}$, and $\mathrm{C}$ is $158.7805 \mathrm{MWh}, 261.17 \mathrm{MWh}$, and 233,69 MWh respectively.

\subsection{Efficiency of The System}

$$
\eta_{\text {system }}=\frac{E_{\text {turbin }}}{E_{\text {pompa }}} \times 100 \%
$$

The efficiency of the PSH system is obtained by using (18) above. The efficiency of the PSH system in each layout design of pipeline in this study are $75.460 \%$ for the design A, $56.204 \%$ for the design B, and $63.967 \%$ for the design $\mathrm{C}$ (see Table 1).

\section{Results and Discussion}

The starting operation time based on the natural water availability is 14.7 years from the year 2014. In that time, the upper reservoir water level is $-0.087 \mathrm{~m}$ and the lower reservoir water level is $-48.002 \mathrm{~m}$. The efficiency of the PSH system is influenced by some variables. They are the pipeline design, volume of water that will flow, headloss and operational time per cycle.

Where :

pump: the flow rate of the pumping system $(\mathrm{m} / \mathrm{s})$

$\eta$ : efficiency of the pumping system 
Table 1. Comparison of the Three Designs

\begin{tabular}{|c|l|}
\hline Length & $\begin{array}{l}\text { Based on the layout design, the length of } \\
\text { design A < design C < design B. The } \\
\text { longer pipeline, the bigger headloss, and } \\
\text { friction generated }\end{array}$ \\
\hline $\begin{array}{c}\text { Maximum } \\
\text { Turbine Power }\end{array}$ & $\begin{array}{l}\text { The maximum turbine power of design A } \\
<\text { design C < design B. The difference is } \\
\text { caused by the amount of head loss } \\
\text { generated. The bigger headloss } \\
\text { generated, the less maximum turbine } \\
\text { power generated }\end{array}$ \\
\hline $\begin{array}{c}\text { Operational } \\
\text { Cycle }\end{array}$ & $\begin{array}{l}\text { The pump and turbine operational time of } \\
\text { design A < design C < design B. The } \\
\text { longer pipeline, the more time needed to } \\
\text { flow the water. The operational time } \\
\text { difference per cycle between pump and } \\
\text { turbine is 0.25 hours for pipeline A and }\end{array}$ \\
$\begin{array}{c}\text { 0.5 hours for pipeline B. Pipeline C has } \\
\text { the equal pump and turbine operational } \\
\text { time per cycle. }\end{array}$ \\
\hline Energy per & $\begin{array}{l}\text { The energy generated per cycle of design } \\
\text { C < design B }<\text { design A. The design A } \\
\text { has the lowest energy generated than the } \\
\text { others, although it has the smallest head } \\
\text { loss and the highest maximum turbine } \\
\text { power. It is caused by its flow rate, which } \\
\text { is the smallest than others. The highest } \\
\text { flow rate is in the design B, but its } \\
\text { generated energy is lower than that } \\
\text { generated by the design C. The higher } \\
\text { head loss in the design B causes lower } \\
\text { generated energy. }\end{array}$ \\
\hline Efficiency & $\begin{array}{l}\text { The efficiency generated by the system } \\
\text { per cycle of the design A }<\text { the design C } \\
<\text { the design B. }\end{array}$ \\
\hline
\end{tabular}

\section{References}

[1] S.H. Siahaan, T.A. Murwanto, S. Dolant, "Inovasi Teknologi PLTMH dan PLTB Lembaga Litbang Pemerintah". Jakarta, LIPI Press, 2011 (in Bahasa Indonesia)

[2] Badan Perijinan dan Penanaman Modal Daerah (BPPMD) Kalimantan Timur. "Penyusunan Kajian Investasi di Lahan Eks Tambang". Technical Document. Samarinda, 2012 (in Bahasa Indonesia)

[3] H.M. Ramos, M.P. Amaral, D.I.C. Covas, Journal of Water Resource and Protection 6, 1099-1111 (2014)

[4] J. Olsen, K. Paasch, B. Lassen, C.T. Veje, Journal of Energy Storage 2, 54-63 (2015)

[5] S. Kucukali, Renew. Sust. Energ. Rev 37, $502-$ 508. (2014)

[6] S. Padron, J.F. Medina, A. Rodriguez, Energy 36, 6753-6762. (2011)

[7] D.A. Katsaprakakis, D.G. Christakis, I. Stefanakis, P.Spanos, N. Stefanakis, Energy 55, 619-630 (2013)

[8] BMKG, "Jumlah Curah Hujan dan Jumlah Hari Hujan di Stasiun Pengamatan BMKG 2000-2013". Accessed from www.bps.go.id on April 1, 2016.
[9] S.M. Indriani, Analisis Kebutuhan Air, Irigasi Pangan dan Energi PLTMH (Pembangkit Listrik Tenaga Mikrohidro) Sungai Bayang, Kecamatan Bayang Utara, Kabupaten Pesisir Selatan. Thesis. Departement of Nuclear Engineering and Engineering Physics, Faculty of Engineering, Universitas Gadjah Mada, Yogyakarta, 2016. (in Bahasa Indonesia) 